\title{
Forecast of Impacts of Climate Change on Hydropower Potential of Ouémé River at the 2040's Horizon in Benin
}

\author{
Télesphore Cossi Nounangnonhou ${ }^{1,2, ~ *, ~ F r a n c ̧ o i s-X a v i e r ~ N i c o l a s ~ F i f a t i n ~}{ }^{1}$, \\ Richy Maurel Aza-Gnandji ${ }^{1}$, Amevi Acakpovi ${ }^{3}$, Emile Adjibadé Sanya ${ }^{2}$ \\ ${ }^{1}$ Department of Electrical Engineering, University of Abomey-Calavi, Calavi, Benin \\ ${ }^{2}$ Department of Mechanical and Energetic Engineering, University of Abomey-Calavi, Calavi, Benin \\ ${ }^{3}$ Department of Electrical and Electronic Engineering, Accra Technical University, Accra, Ghana
}

\section{Email address:}

nocteles2000@gmail.com (T. C. Nounangnonhou), fifatinf@gmail.com (François-Xavier N. F.), maurel.aza@gmail.com (R. M. Aza-Gnandji), acakpovia@gmail.com (A. Acakpovi), easanyas@hotmail.com (E. A. Sanya)

*Corresponding author

\section{To cite this article:}

Télesphore Cossi Nounangnonhou, François-Xavier Nicolas Fifatin, Richy Maurel Aza-Gnandji, Amevi Acakpovi, Emile Adjibadé Sanya. Forecast of Impacts of Climate Change on Hydropower Potential of Ouémé River at the 2040's Horizon in Benin. International Journal of Energy and Power Engineering. Vol. 7, No. 1, 2018, pp. 6-18. doi: 10.11648/j.ijepe.20180701.12

Received: February 7, 2018; Accepted: February 27, 2018; Published: March 16, 2018

\begin{abstract}
Water is the most essential element for hydropower energy production. However, it has been well established that climate change will negatively globally impact water resources and in Sub-Saharan Africa particularly. It is therefore important to take this into account when assessing the potential hydropower energy of rivers to avoid overestimating their production's capacity. This article firstly deals with the impacts of climate change on the forecast of potential hydropower energy of the Ouémé River Basin by 2040 and secondly develops the best equations for its exploitation. The data collected on three representative sites of the Ouémé River Basin (Bétérou, Savè, Kétou) from 1989 to 2016 and those derived from simulation of its flows from 2017 to 2040 by the Rural Engineering model (GR2M), made it possible to determine, first the monthly mean flow and, with the classified flow rate method, then evaluate the associated operating times. Using the obtained two parameters (mean flow-rate, production's time), the hydropower energy was estimated as well, for period of 1989 to 2016, as for that of 2017 to 2040, and this in each of the retained three sites. The results show that the exploitable nominal flow-rates by hydroelectrical equipment set that can be installed are respectively $50 \mathrm{~m}^{3} / \mathrm{s}$ at Bétérou, $90 \mathrm{~m}^{3} / \mathrm{s}$ at Savè and $145 \mathrm{~m}^{3} / \mathrm{s}$ at Kétou. These results showed Kétou as the best site capable of hosting the largest hydropower energy plant on the Ouémé river basin. In Bétérou and Savè, the two-machines option (respectively $25 \mathrm{~m}^{3} / \mathrm{s}$ and $45 \mathrm{~m}^{3} / \mathrm{s}$ ) is the most profitable, in terms of potential hydropower energy and its production duration, whereas in Kétou, the three-machines option of $50 \mathrm{~m}^{3} / \mathrm{s}$ each is the best.
\end{abstract}

Keywords: Forecast, GR2M, Climate Change, Ouémé River, Simulation, Hydropower Energy

\section{Introduction}

With $16 \%$ of global power generation [1], hydropower energy is the third largest source of global electricity generation, behind coal (41\%) and gas (21\%). Some countries have adopted hydropower energy as the main source of energy. It is the case in Canada where majority (almost 97\%) of the electricity consumed in Quebec is based on hydropower energy [1]. The Republic of Benin belongs to the category of countries least served in electricity. The energy situation in Benin is characterized by a low level of per capita energy consumption, a significant use of traditional energies (biomass) and fossil hydrocarbons and a potential hydropower energy whose exploitation is at an embryonic stage [2]. Faced with this situation, the new energy policy country, through "Bénin 2025 Water Vision", favored the development of hydropower energy in general and the development of the potential of Ouémé river basin in particular [2].

However, it has been established that climate change will affect water resources [3]. The situation concerns hydropower energy generation sector, as water is the main 
source for such power generation system [4]. In Benin, we are witnessing more and more extreme weather events: disruption of season's alternation, temperature rise and changes in hydrological regimes [5]; [6]. The first studies carried out concerning the hydro-climatic variability and the hydrological flow of the Ouémé catchment in Bétérou have clearly shown a rainfall deficit at the inter-annual scale of nearly $20 \%$ and an inter-annual variability of the rainfallflow ratio since the 70s [7]. This combination of temperature rise and fall in rainfall would result, according to several studies, in lower flows, leading to a decrease in hydropower energy generating capacity [8]. The extent of changes affecting hydrological cycle can vary from one basin to another [9].

However, the influence of climate change on the hydrological regime of the Ouémé River Basin has not been highlighted in the predictions made so far by previous studies. The integration of impacts of the latter is essential in a realistic prospective approach and should make it possible to improve the efficiency of the simulated flows and subsequently that of hydropower energy production of the basin.

The objective of the present investigation is therefore to take into account the impacts of climate change in the forecast analysis of potential hydropower energy of the Ouémé river basin by 2040 .

\section{Material and Methods}

\subsection{Study Zone}

The Ouémé river basin (Figure 1) covers an area of 47,000 $\mathrm{km}^{2}$, about $43 \%$ of the country's area [10].

Located between 6.8 and $10.2^{\circ}$ Latitude North, the Ouémé basin is characterized by a transition from the Sudannean climate in the North with an average year precipitation of 900 to $1000 \mathrm{~mm}$, to the Beninese climate in southern with an average year rainfall of $1200 \mathrm{~mm}$. About $89 \%$ of the Ouémé river basin is located in Benin, $10 \%$ in Nigeria and $1 \%$ in Togo [11]. The Ouémé river basin records an mean annual temperature of $26^{\circ} \mathrm{C}$ to $30^{\circ} \mathrm{C}$ [11]. From a hydrological perspective, this river basin is characterized by lower and lower flows and the early drying up of seasonal courses [12]. The Ouémé River, which is $510 \mathrm{~km}$ long and has the two largest tributaries, flows to Lake Nokoué $\left(150 \mathrm{~km}^{2}\right)$ and ends up into the sea through the coastal lagoon [13]. Precipitation water, which flows into the basin, is subdivided into water intercepted by plants, water retained by the soil, infiltrated water and water flowing at soil surface [14]. All of the water intercepted and some of the water retained by the soil are lost through evaporation and transpiration [15]. Surface water is an important part of the flow at the outlet.

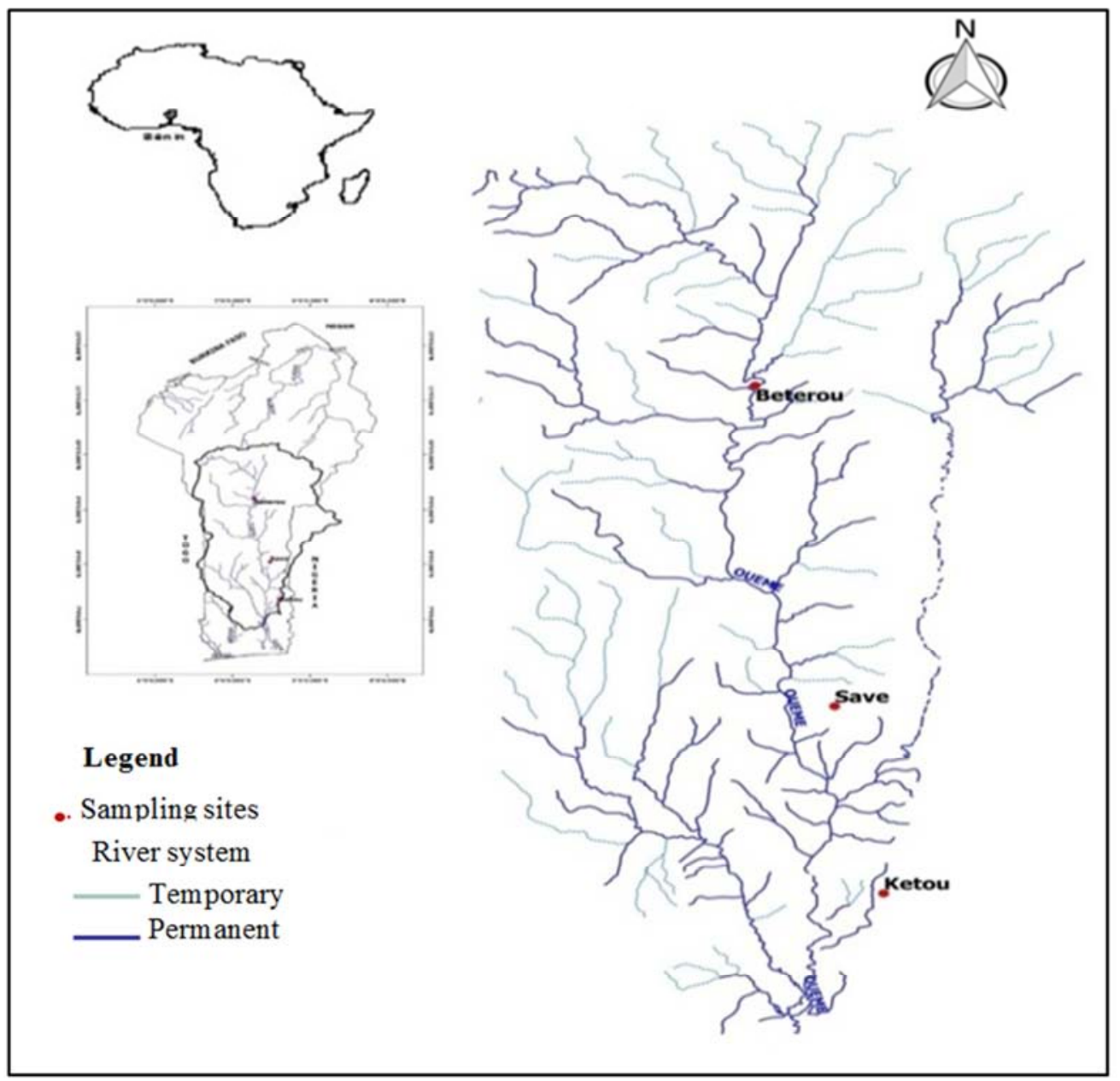

Figure 1. Description of Basin flowing from Ouémé river. 


\subsection{Data Used}

The data series used are those relating to daily water level, the daily flow and the natural elevations (natural drop heights) of three characteristic sites: Bétérou, Savè and Kétou, which are fairly representative of the different zones of the studied river basin. The first two data come from the Laboratory of Climate, Water, Ecosystems and Development (LACEEDE) of the University of Abomey-Calavi (Benin). Those for natural fall height of sites are obtained at the General Directorate of Energy (DGE) of Cotonou (Benin). These water level and flow data are based on the daily values recorded in 20 stations (including 3 synoptic types) located near the study area from 1989 to 2016 . Monthly mean flowrates from 2017 to 2040 are derived from simulation performed using the GR2M model [16]. In fact, the results of this study revealed that climate change could, in the next 25 years, induce impacts leading to reductions in mean annual flow-rates of about 11.90 to $46.37 \%$ of hydrological regime of the Ouémé river basin region. This justifies the use of these flow-rates in the present works to analyze the future behavior of potential hydropower energy of the Ouémé river basin through its three characteristic sites of Bétérou, Savè and Kétou.

\subsection{Methods}

From the previously presented data, the graph of the flow versus the water level in river basin at each of the three reference sites is carried out in Microsoft Excel.10 environment which has made it possible to establish the correlations existing between two variables for assessing the potential hydropower energy stations of the various sites. Then, monthly average flow-rates, on basis of the available inter-annual flows data, were determined over the 1989 2016 period using the arithmetic average of un-weighted statistical series.

$$
\mathrm{Q}_{\mathrm{i}}=\frac{\sum_{\mathrm{j}=1}^{28}\left(\mathrm{a}_{\mathrm{i}, \mathrm{j}}\right)}{\mathrm{m}}
$$

$i$ : the months of a year;

$j:$ the years of the period $1989-2016$;

$\mathrm{Q}_{\mathrm{i}}$ : the mean monthly throughput of month $\mathrm{i}$ over the period 1989 - 2016;

$a_{i, j}$ : the mean monthly flow of month $\mathrm{i}$ and year $\mathrm{j} ; \mathrm{m}=28$ : the number of years contained in the period $1989-2016$. Once the inter-annual monthly average flow-rates have been obtained, a reserved flow-rate was extracted at a rate value of $20 \%$ [17]. Indeed, the reserved flow-rate ensures not only the continuity of flow of the river, but also provides a considerable quantity of water for other uses, especially in case of power failure. Furthermore, the flow-rate method [18] was used to determine the equipment's flow or nominal flowrate $Q_{n}$, favouring optimal production of hydropower energy at each site. This method consists of classifying, in descending order, the flow-rates obtained $\left(80 \% Q_{i}\right)$ after subtraction of the reserved flow-rate $\left(20 \% Q_{i}\right)$ and also to search among the twelve possible monthly values for turbine power supply, the optimal value for the annual potential hydropower energy function defined as follow:

$$
\mathrm{E}(\mathrm{GWh})=\sum_{\mathrm{i}=1}^{12} \mathrm{P}\left(\mathrm{Q}_{\mathrm{i}}, \mathrm{H}_{\mathrm{i}}\right) \cdot \mathrm{T}_{\mathrm{i}}
$$

Where $\mathrm{P}\left(\mathrm{Q}_{\mathrm{i}}, \mathrm{H}_{\mathrm{i}}\right)$ is the potential hydropower (Michel \& Yves, 2009) expressed in Gigawatt $(\mathrm{GW})$ and $E(\mathrm{GWh})$ is potential hydropower energy.

$$
\begin{array}{r}
\mathrm{P}\left(\mathrm{Q}_{\mathrm{i}}, \mathrm{H}_{\mathrm{i}}\right)=\frac{9.81 \cdot \mathrm{Q}_{\mathrm{i}} \cdot \mathrm{H}_{\mathrm{i}}}{1000} \\
\text { With: } \mathrm{H}_{\mathrm{i}}=\mathrm{h}_{0}+\mathrm{h}_{\mathrm{i}}
\end{array}
$$

where

$Q_{i}$ : the inter-annual monthly average flows-rate of month i expressed in cubic meters per second $\left(\mathrm{m}^{3} / \mathrm{s}\right)$;

$H_{i}$ : total fall of water during the month $\mathrm{i}$ (difference between the upstream level and the downstream level of the plant;

$T_{i}$ : the monthly production time associated with the rate $Q_{i}$ expressed in hours $(\mathrm{h})$;

$h_{0}$ : the natural fall of the hydropower energy plant (natural elevation of the site);

$h_{i}$ : the water level upstream of the water reservoir during the month $i$.

Based on the river flow-rate and water level data collected on the Bétérou, Savè and Kétou sub-basins, flow-height curves were produced in the Microsoft Excel 10 environment, which allowed the modelling of water heights hi of each site according to flow-rates. Finally, evaluation of the annual potential hydropower energy was subjected to the following constraints:

$$
\begin{gathered}
\text { * If } Q_{i} \geq 1.25 . Q_{n} E(G W h)=\sum_{i=1}^{12} P\left(Q_{n}, H_{i}\right) \cdot T_{i} \\
* \text { If } Q_{n} \leq Q_{i}<1.25 . Q_{n} \\
E(G W h)=\sum_{i=1}^{12} P\left(0.8 \cdot Q_{n}, H_{i}\right) \cdot T_{i} \\
\text { * If } Q_{i}<Q_{n} P\left(Q_{i}, H_{i}\right)=0 \text { and } T_{i}=0
\end{gathered}
$$

This approach makes it possible to consider, at the same time, the effects of climate change on the flow of the Ouémé river, and on the time of production because it has been established that the climate changes are also observed on the Ouémé basin by the tightening of the rainy seasons and, consequently, impact the flow duration of the river [19].

For a better management of the hydrological resources in 
hydropower energy production, three possible options (scenarios) have been simulated for the purpose not only to propose the optimal number of turbines to be installed at each of the three representative sites of the Ouémé river basin, but also to improve their respective performances. They essentially consist in carrying out a reduction of the potential electrical power of the various sites by simulating the installation of several turbines whose sum of powers is equal to the nominal power in each site. In this series of simulations, we have assumed that current anthropogenic water withdrawals are negligible and will not increase in the future.

For each of the three options evaluated, the graphs of the annual potential hydropower energy, versus the annual production time and the histogram of the monthly mean electrical potential were established, using the Excel and $\mathrm{R}$ softwares, on the basis of the data observed from 1989 to 2016 as well as with simulated data from 2017 to 2040. Finally, the rate of change of the potential hydropower energy was determined in each case.

\section{Results and Discussions}

\subsection{Flow-water Curves on the Studied Sites}

Figure 2 illustrates water head vs. flow graphs obtained on the three representative sites of the Ouémé River basin (in dotted blue) with the respective correlations (in black continuous line). Indeed, one notice that water height (h)

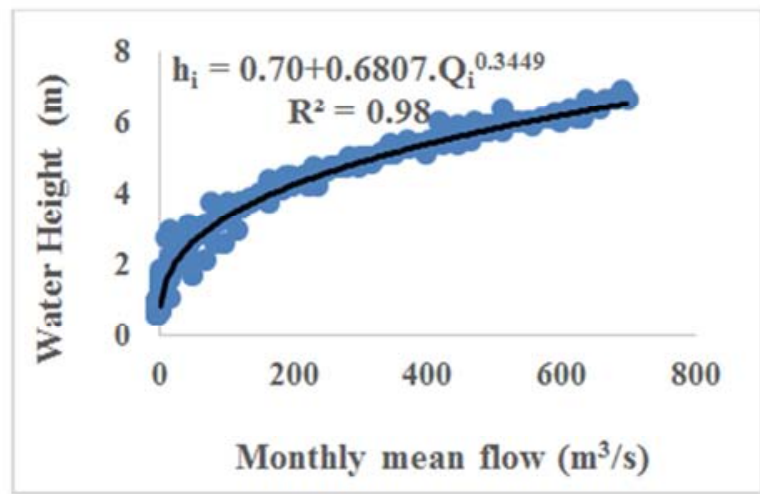

(a)

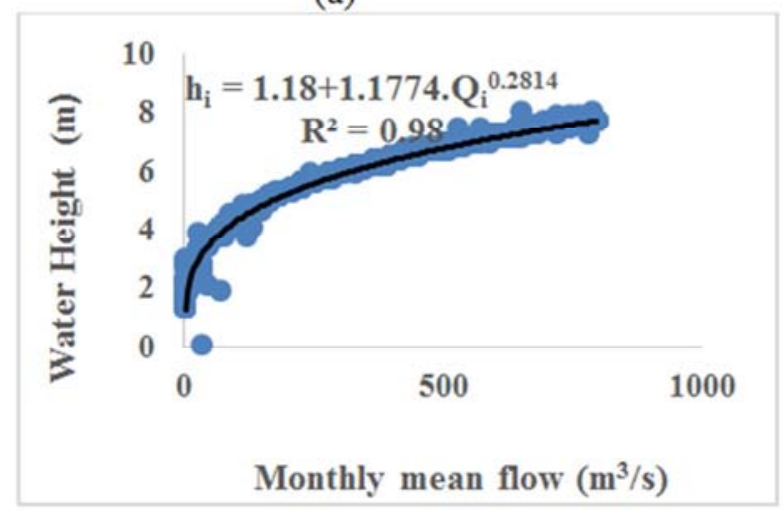

(c) evolution in function of flow-rates (Q) could be adequately modeled respectively by the trend equations on the sites as follow:

* Savè:

$$
\mathrm{h}_{\mathrm{i}}=0.70+0.6807 \cdot \mathrm{Q}_{\mathrm{i}}^{0.3449} \mathrm{R}^{2}=0.9874(\mathrm{~m})
$$

* Bétérou:

$$
\mathrm{h}_{\mathrm{i}}=0.92+0.9224 \cdot \mathrm{Q}_{\mathrm{i}}^{0.3293} \mathrm{R}^{2}=0.9586(\mathrm{~m})
$$

* Kétou:

$$
\mathrm{h}_{\mathrm{i}}=1.18+1.1774 \cdot \mathrm{Q}_{\mathrm{i}}^{0.2814} \mathrm{R}^{2}=0.9768(\mathrm{~m})
$$

From these results, various coefficients leading to the determination of R2 show a strong correlation between the two parameters, whatever the considered site. In addition, for all the sites, the dry-out levels of the basins (level $\mathrm{h}$ from which there is no more flow i.e. $\mathrm{Q}=0$ ) are respectively 0.70 $\mathrm{m}$ at Savè, $0.92 \mathrm{~m}$ at Bétérou and $1.18 \mathrm{~m}$ at Kétou. Equations (8), (9), and (10) thus, defined respectively on the reference sites of the study, between water level and flow-rate are then used in determination of the hydropower energies that can be generated. These results clearly indicate that not only does the Kétou site have a higher monthly mean flow-rate, but also its basin has a higher water head upstream than the other two sites.

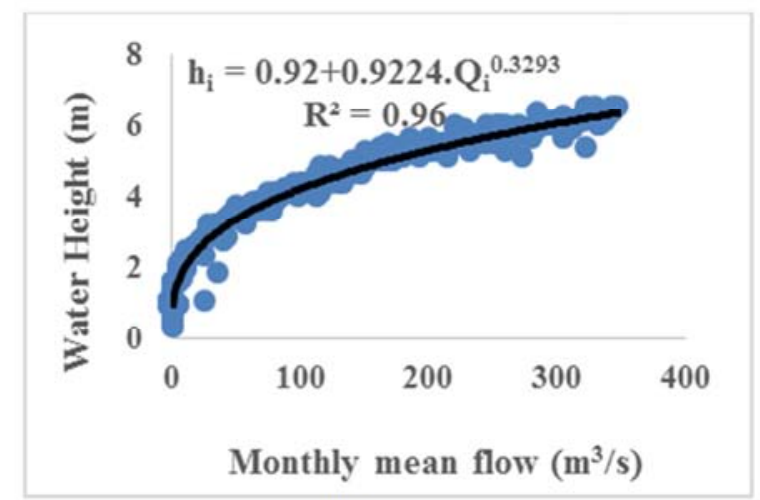

(b)

Legend

00000 Water Head vs. Flow

Correlation coefficient

(a) Water Head versus Flow at Savè; (b) Water Head versus Flow at Bétérou; (c) Water Head versus Flow at Kétou.

Figure 2. Water Height versus Flow correlation for Savè, Bétérou and Kétou sites. 


\subsection{Nominal Equipment's Flow-rate that can be Implemented at Each Site}

The nominal flow-rates of equipment obtained at the three representative sites are of $50 \mathrm{~m}^{3} / \mathrm{s}, 90 \mathrm{~m}^{3} / \mathrm{s}$, and $145 \mathrm{~m}^{3} / \mathrm{s}$ respectively at Bétérou, Savè and Kétou. These values reveal that the Kétou site is positioned as one that can accommodate the largest hydropower energy plant amongst the three. In addition, with regard to the water flow-rates recorded at Kétou, its generation capacity can surpass the sum of the production capacities of the two other sites.

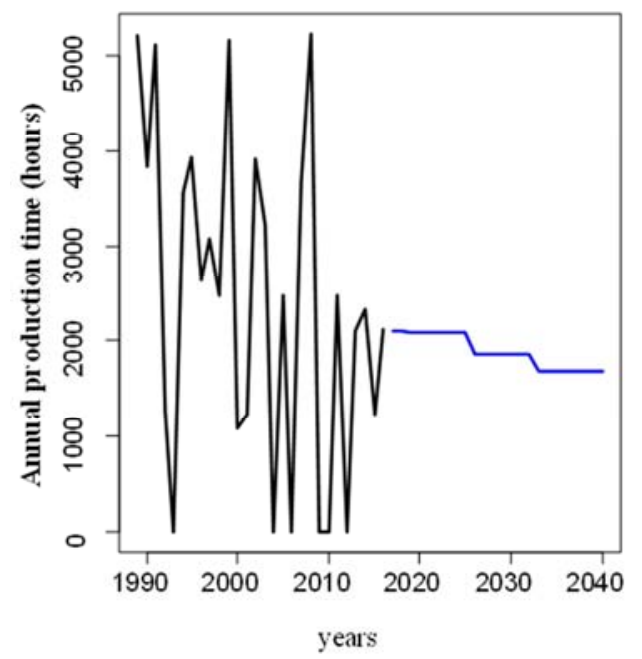

(a)

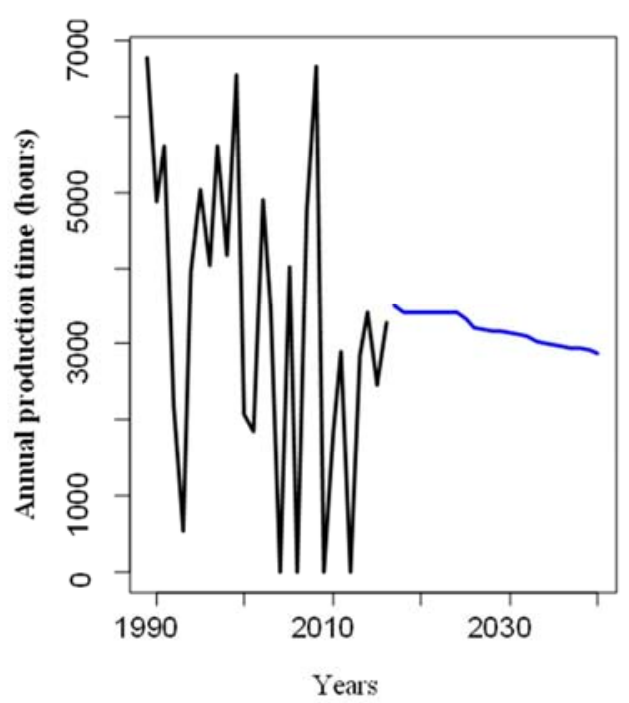

(c)
These results confirm the trends presented in the report of the study carried out in 2008 and presented in the policy and strategy document for development of electric power sector in Benin [20].

\subsection{Site of Bétérou}

\subsubsection{Annual Production Time}

Figure 3 presents the annual production time (expressed in hours) at the Bétérou site for the respective periods of 19892016 and 2017-2040.

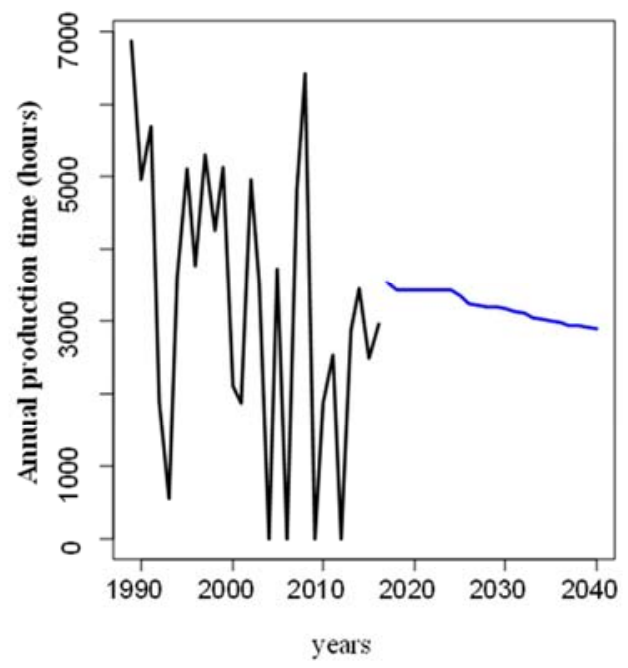

(b)

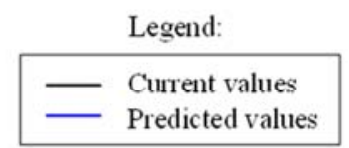

(a) Case of a Single turbine of $50 \mathrm{~m}^{3} / \mathrm{s}$; (b) Case of Double turbines of $25 \mathrm{~m}^{3} / \mathrm{s}$; (c) Case of Triple turbines of $17 \mathrm{~m}^{3} / \mathrm{s}$.

Figure 3. Annual production time for the period of 1989-2016 and 2017-2040 at the Bétérou site.

With regard to Figure 3, it is noted that the options with two or three turbines present almost the same paces and show a substantial change in the annual production time compared to that of a single turbine. Moreover, the latter reveals, over the future period (2017-2040), two break points respectively in the years 2026 and 2033 with stationary zones over the periods of 2017-2025, 2026-2032 and 2033-2040. For the options with two and three turbines respectively, there is a slight decrease in annual production time over the future period. As indicated in Table 1, hydropower energy generation time could be significantly impacted by future climate change. 
Table 1. Annual production time of hydropower energy based on the three options at Bétérou site.

\begin{tabular}{lllll}
\hline $\begin{array}{l}\text { Annual mean production time for the } \\
\text { period: }\end{array}$ & Units & $\begin{array}{l}\text { Single Turbine }\left(\mathbf{5 0} \mathbf{~ m}^{\mathbf{3}} / \mathbf{s}\right) \\
\text { option }\end{array}$ & $\begin{array}{l}\text { Double Turbine }\left(\mathbf{2 5} \mathbf{~ m}^{\mathbf{3}} / \mathbf{s}\right) \\
\text { option }\end{array}$ & $\begin{array}{l}\text { Triple Turbine }\left(\mathbf{1 7} \mathbf{~ m}^{\mathbf{3}} / \mathbf{s}\right) \\
\text { option }\end{array}$ \\
\hline $1989-2016$ & $\mathrm{H}$ & 2,405 & 3,244 & 3,352 \\
$2017-2040$ & $\mathrm{H}$ & 1,888 & 3,202 & 3,182 \\
Drop rate & $\%$ & 21.48 & 1.29 & 5.06 \\
\hline
\end{tabular}

In addition, it is noted that the single-turbine option for hydropower energy generation is the one that will suffer in the future, the highest drop rate $(21.48 \%)$, compared to the two turbines option. The latter appears to be the best for the annual hydropower energy production time in Bétérou and offers not only the lowest drop rate $(1.29 \%)$ but also projects for the future period (2017-2040), the highest rate of improved production time: $69.60 \%$ compared to singleturbine option.

\subsubsection{Potential Hydropower Energy}

\section{a. Monthly Distribution of Potential Hydropower Energy}

Figure 4 shows the monthly distribution of potential mean hydropower energy generation. It shows that current and future electricity generation on the Ouémé River in Bétérou are spreading from July to October for the two turbines and three turbines production options, contrary to the single turbine option which offers only two months of production in the future: August and September. It is also noted that future productions could exceed the current one in September in Bétérou. From these results, it appeared that in the years to come, there could be a narrowing in the distribution of annual potential hydropower energy of the Ouémé river basin on Bétérou site.

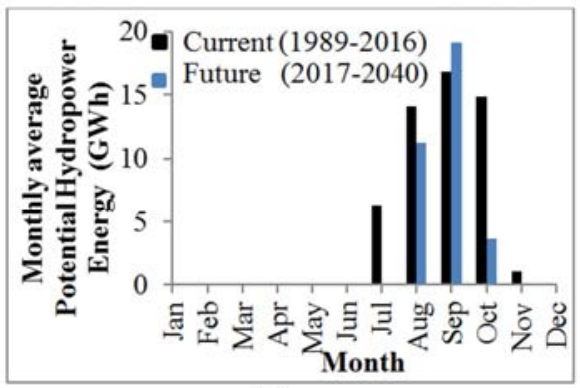

(a)

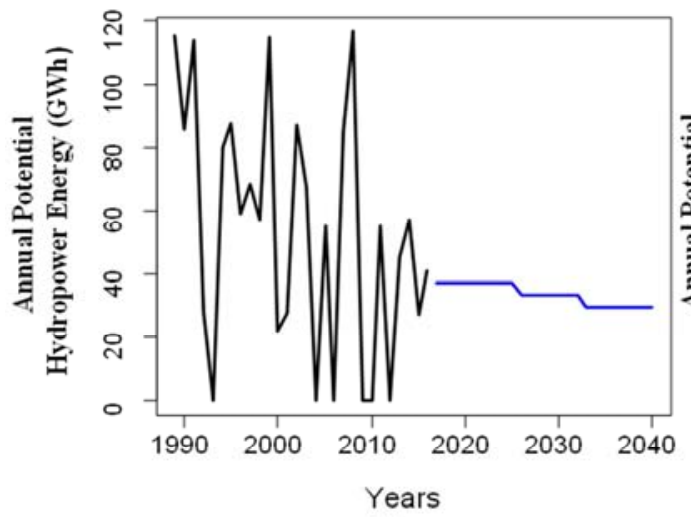

(a)

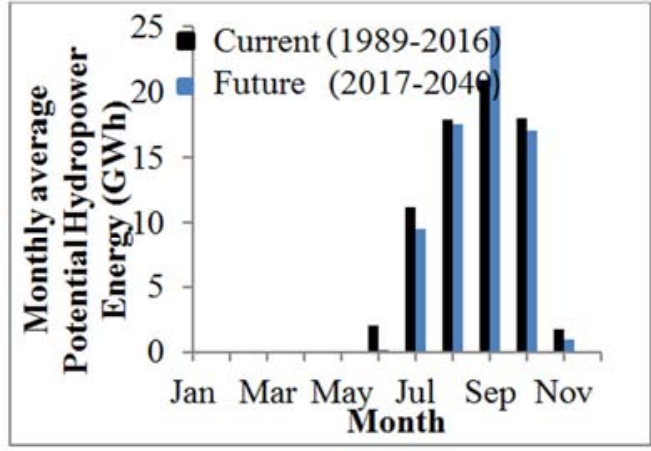

(b)

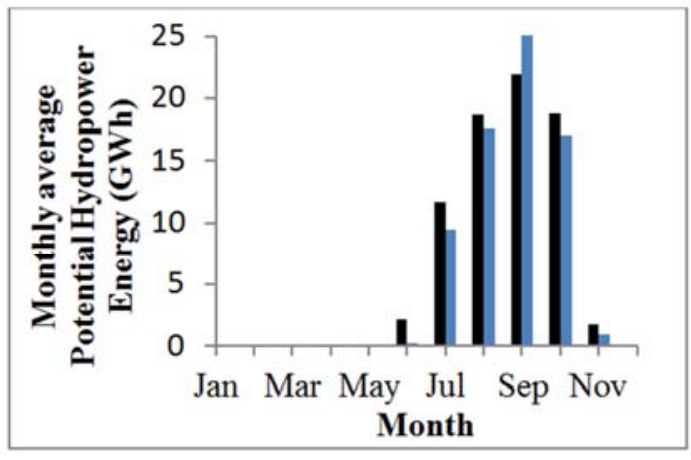

(c)

Figure 4. Monthly mean potential hydropower energy of the Ouémé on Bétérou site for the period of 1989-2016 and 2017-2040. (a) Case of a Single turbine of $50 \mathrm{~m}^{3} / \mathrm{s}$; (b) Case of Double turbines of $25 \mathrm{~m}^{3} / \mathrm{s}$; (c) Case of Triple turbines of $17 \mathrm{~m}^{3} / \mathrm{s}$.

\section{b. Potential Hydropower Energy Over Time}

Figure 5 shows the evolution of the annual potential hydropower energy according to the three options on Bétérou site.

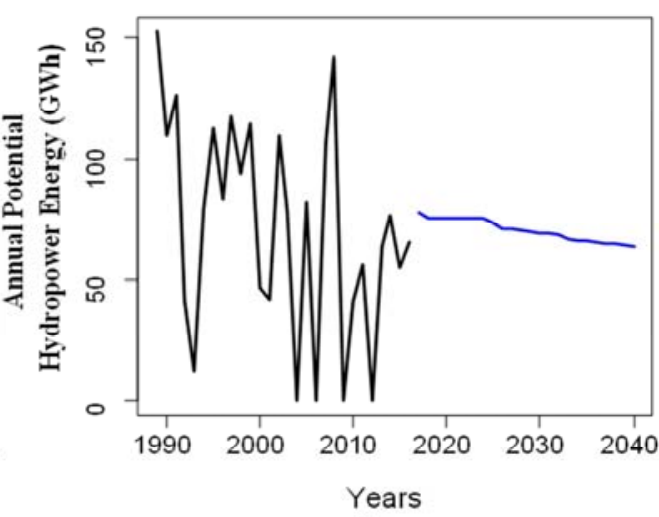

(b) 

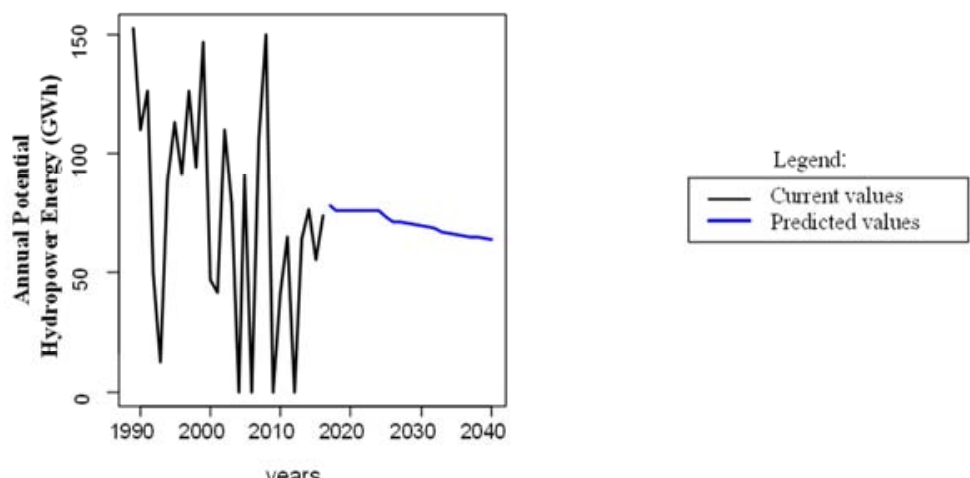

(c)

Figure 5. Annual Potential hydropower energy over time for periods of 1989-2016 and 2017-2040 on Bétérou site. (a) Case of a Single turbine of $50 \mathrm{~m}^{3} / \mathrm{s}$; (b) Case of Double turbines of $25 \mathrm{~m}^{3} / \mathrm{s}$; (c) Case of Triple turbines of $17 \mathrm{~m}^{3} / \mathrm{s}$.

Figure 5 shows a gradual reduction of the annual potential hydropower energy over time, whatever the selected option. Similarly to the observations obtained for the annual production time, the future productions show a decreasing pace over time. However, it is clear that the double and triple turbines options have the same increasing behavior in their future trends as compared to that of a single turbine. The differences observed between the rates of drop in production time and rate of drop in annual mean potential hydropower energy, reveals that in Bétérou, climate change impacts both production time and generated electric power, two important factors related to electrical energy. The impact on electrical power is not significant. This shows that climate change impacts more the annual rainfall duration than the hydrological regime (flow) of the watercourse. Furthermore, it appears that climate change more illustrated by the narrowing of rainy seasons than by the decrease in rainfall amounts. This justifies the weak impact of climate change on the electric power unlike the annual production time.

Table 2 presents the annual average potential hydropower energy at Bétérou site according to the three analysed production options.

Table 2. Annual mean potential hydropower energy according to the three options on the Bétérou site.

\begin{tabular}{lllll}
\hline $\begin{array}{l}\text { Annual potential hydropower } \\
\text { energy for the period: }\end{array}$ & Units & $\begin{array}{l}\text { Single Turbine }\left(\mathbf{5 0} \mathbf{~ m}^{\mathbf{3}} / \mathbf{s}\right) \\
\text { option }\end{array}$ & $\begin{array}{l}\text { Double Turbine }\left(\mathbf{2 5} \mathbf{~ m}^{\mathbf{3}} / \mathbf{s}\right) \\
\text { option }\end{array}$ & $\begin{array}{l}\text { Triple Turbine }\left(\mathbf{1 7} \mathbf{~ m}^{\mathbf{3}} / \mathbf{s}\right) \\
\text { option }\end{array}$ \\
\hline $1989-2016$ & $\mathrm{GWh}$ & 53.96 & 71.86 & 75.32 \\
$2017-2040$ & $\mathrm{GWh}$ & 34.02 & 70.54 & 70.50 \\
Drop Rate & $\%$ & 36.96 & 1.84 & 6.35 \\
\hline
\end{tabular}

As revealed by the summarized results in Table 2, hydropower energy generation could be impacted by climate change in the future. In addition, it is noted that the singleturbine hydropower energy generation option incurred the highest rate of drop of $36.96 \%$ compared to the doubleturbine option which appears to be the best for annual hydropower energy production in Bétérou. Indeed, the latter displays not only the lowest rate of drop (1.84\%), but also offers, for the future period (2017-2040), the highest rate of improvement in production time $107.35 \% \quad(=(70.54-$

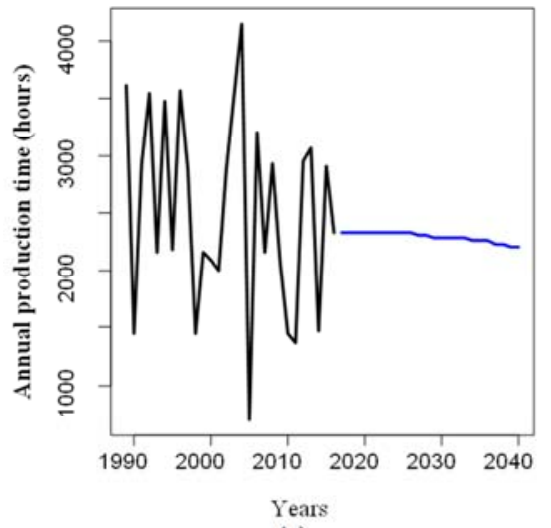

(a)
$34.02) / 34.02)$

\subsection{Site of Savè}

\subsubsection{Simulated Annual Production Time}

The annual mean time for hydropower energy generation at Savè site for the 1989-2016 and 2017-2040 periods respectively, according to the three options adopted earlier is presented in Figure 6.

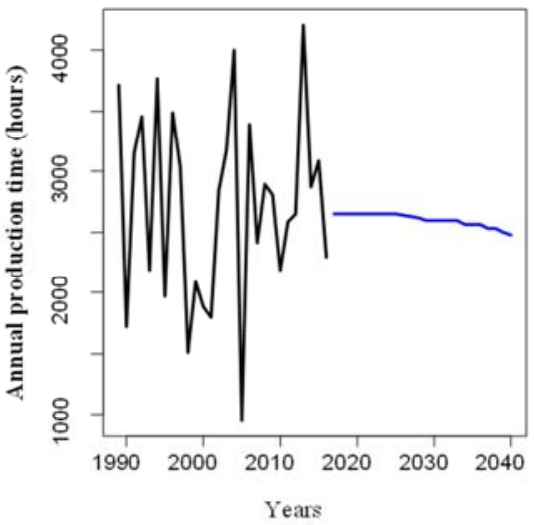

(b) 


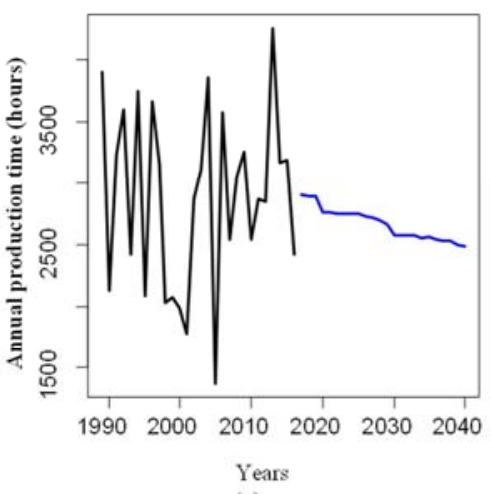

(c)

(a) Case of a Single turbine of $90 \mathrm{~m}^{3} / \mathrm{s}$; (b) Case of Double turbines of $45 \mathrm{~m}^{3} / \mathrm{s}$; (c) Case of Triple turbines of $30 \mathrm{~m}^{3} / \mathrm{s}$.

Figure 6. Annual production time for periods of 1989-2016 and 2017-2040 at Savè site.

On the site of Savè, it can be observed that in the future prediction, the annual production time will be decreasing. In particular, the triple-machines option (c) of $30 \mathrm{~m}^{3} / \mathrm{s}$, has two breakpoints in 2020 and 2030, respectively. With regard to the performances of the simulated options, it appears that the double and triple turbines' options will know a significant improvement in annual production time compared to that in a single turbine for the period of 2017-2040.

Table 3. Annual production time of hydropower energy at Savè site.

\begin{tabular}{lllll}
\hline $\begin{array}{l}\text { Annual mean production time for } \\
\text { the period: }\end{array}$ & Units & $\begin{array}{l}\text { Single Turbine }\left(\mathbf{9 0} \mathbf{~ m}^{\mathbf{3}} / \mathbf{s}\right) \\
\text { option }\end{array}$ & $\begin{array}{l}\text { Double Turbine }\left(\mathbf{4 5} \mathbf{~ m}^{\mathbf{3}} / \mathbf{s}\right) \\
\text { option }\end{array}$ & $\begin{array}{l}\text { Triple Turbine }\left(\mathbf{3 0} \mathbf{~ m}^{\mathbf{3}} / \mathbf{s}\right) \\
\text { option }\end{array}$ \\
\hline $1989-2016$ & $\mathrm{H}$ & 2,523 & 2,721 & 2,887 \\
$2017-2040$ & $\mathrm{H}$ & 2,289 & 2,607 & 2,669 \\
Drop rate & $\%$ & 9.27 & 4.19 & 7.55 \\
\hline
\end{tabular}

The results presented in Table 3 reveal that the hydropower energy generation time could also be strongly impacted by climate change in the future forecast at Savè. It is still apparent from Table 3 that the single-turbine hydropower energy generation option of $90 \mathrm{~m}^{3} / \mathrm{s}$ is the one with the highest rate of drop $(9.27 \%)$, unlike the double turbine $45 \mathrm{~m}^{3} / \mathrm{s}(4.19 \%)$. The double and triple turbines' options at the Savè site yielded improved annual production time of $13.89 \%$ and $16.60 \%$, respectively, compared to the single-turbine of $90 \mathrm{~m}^{3} / \mathrm{s}$.

\subsubsection{Potential Hydropower Energy}

\section{a. Monthly Distribution of Potential Hydropower Energy}

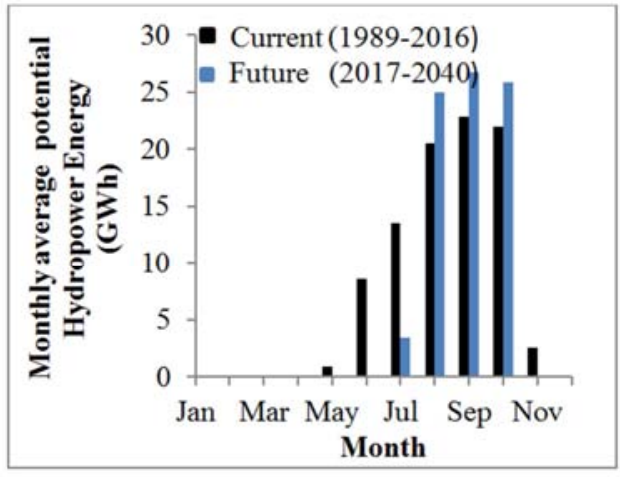

(a)

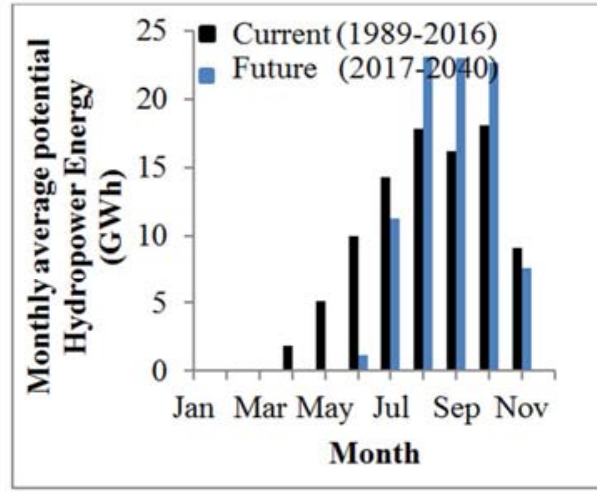

(b)

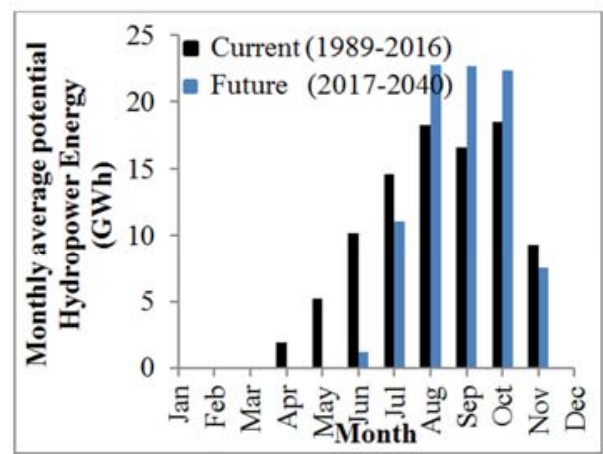

(c)

Figure 7. Monthly average potential hydropower energy of the Ouémé river basin for periods of 1989-2016 and 2017-2040 at Savè site. (a) Case of a Single turbine of $90 \mathrm{~m}^{3} / \mathrm{s}$; (b) Case of Double turbines of $45 \mathrm{~m}^{3} / \mathrm{s}$; (c) Case of Triple turbines of $30 \mathrm{~m}^{3} / \mathrm{s}$. 
Figure 7 shows the distribution of the potential hydropower energy production of Ouémé River on the site of Savè. It is observed that the production is spread out from May to November in the period of 1989 to 2016. That of the future (2017-2040) is extended from July to November for the double and triple turbines' options while the single turbine option covers August to October. In Savè, forecast of hydropower energy production (2017-2040) will have a strong chance to quantitatively exceed current productions for the three months of August, September and October.

\section{b. Potential Hydropower Energy over Time}

Figure 8 shows the annual potential hydropower energy of the Savè site according to three options over the respective periods of 1989 - 2016 and 2017 - 2040.

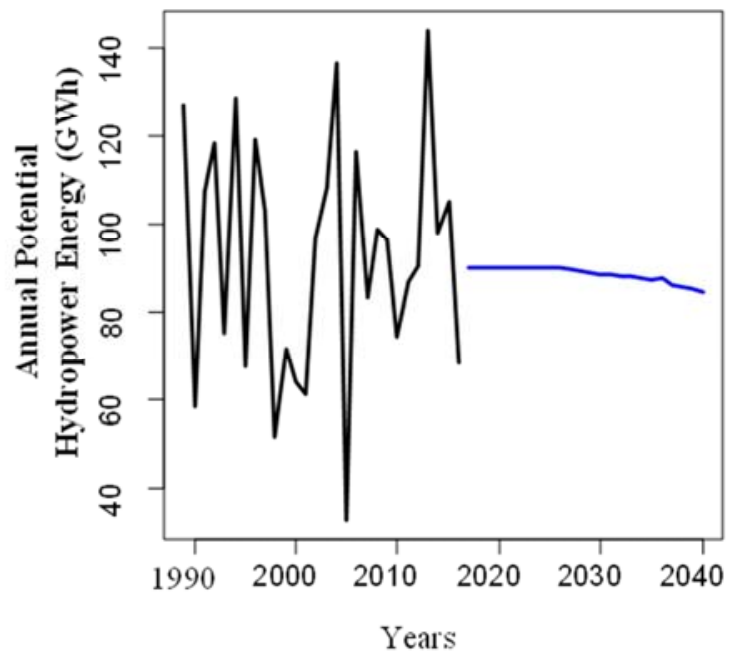

(b)
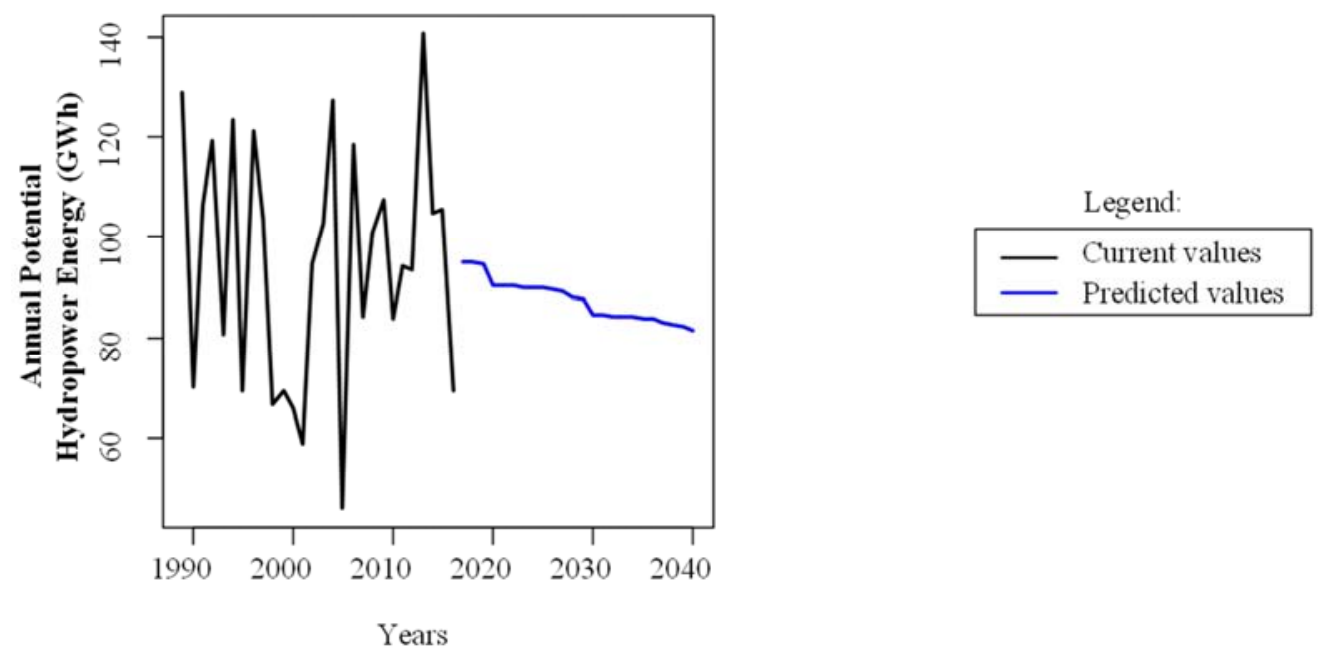

(c)

Figure 8. Annual potential hydropower energy over time for periods of 1989-2016 and 2017-2040 at Savè site. (a) Case of a Single turbine of $90 \mathrm{~m}^{3} / \mathrm{s}$; (b) Case of Double turbines of $45 \mathrm{~m}^{3} / \mathrm{s}$; (c) Case of Triple turbines of $30 \mathrm{~m}^{3} / \mathrm{s}$.

The graph shows a gradual decrease in annual potential hydropower energy over time regardless of the option chosen. Similarly to the annual production time, it is noted that the forecasted hydropower energy productions have a decreasing pace. However, it is clear that the double and triple turbine options exhibit the same behavior in their forecast with significant increases in hydropower energy production compared to single-turbine option. For all the options, the graphs of energy production are similar to those of the production times. This indicates that the method of determining the nominal flow rate rather minimizes the impacts of climate change on the hydropower energy only based on the hydrological flow (a natural climatic parameter) contrary to the production time. The production time could be well controlled by tools for water resources management.

For an in-depth analysis of the results obtained in this investigation, a comparative study of the performance of simulated options is carried out and presented in Table 4. 
Table 4. Annual average potential hydropower energy according to the three turbines' options at Savè site.

\begin{tabular}{|c|c|c|c|c|}
\hline $\begin{array}{l}\text { Annual mean potential for } \\
\text { the period: }\end{array}$ & Units & Single Turbine $\left(90 \mathrm{~m}^{3} / \mathrm{s}\right)$ option & $\begin{array}{l}\text { Double Turbine }\left(45 \mathrm{~m}^{3} / \mathrm{s}\right) \\
\text { option }\end{array}$ & Triple Turbine $\left(30 \mathrm{~m}^{3} / \mathrm{s}\right)$ option \\
\hline $1989-2016$ & GWh & 89.97 & 92.69 & 94.92 \\
\hline $2017-2040$ & GWh & 81.00 & 88.72 & 87.48 \\
\hline
\end{tabular}

Table 4 clearly shows that hydropower energy generation could be strongly impacted by climate change in the future. In addition, it should be noted that the single-turbine option of $90 \mathrm{~m}^{3} / \mathrm{s}$ has the highest drop rate of $9.96 \%$, unlike the double turbine option of $45 \mathrm{~m}^{3} / \mathrm{s}$. The latter appears to be the best option for annual hydropower energy production in Savè. In fact the double turbine option exhibits not only, the lowest drop rate $(4.28 \%)$, but offers the highest rate of production time in the order of $9.53 \%((88.72-81) / 81)$ for the forecast period of 2017-2040, in comparison with the single turbine option.

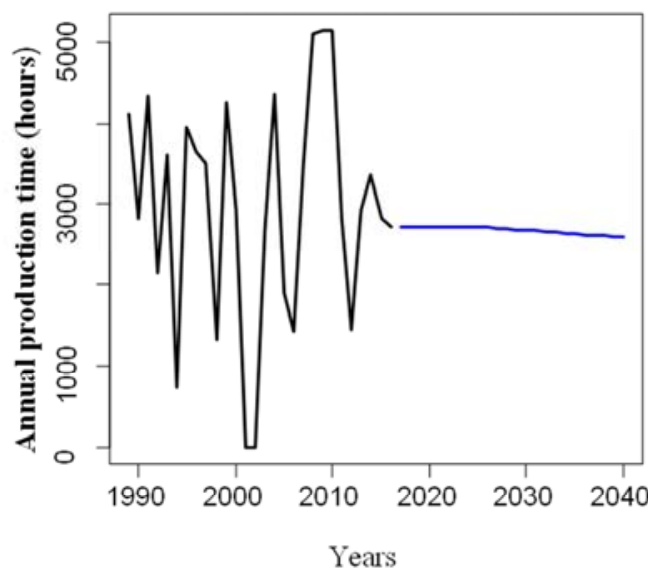

(a)

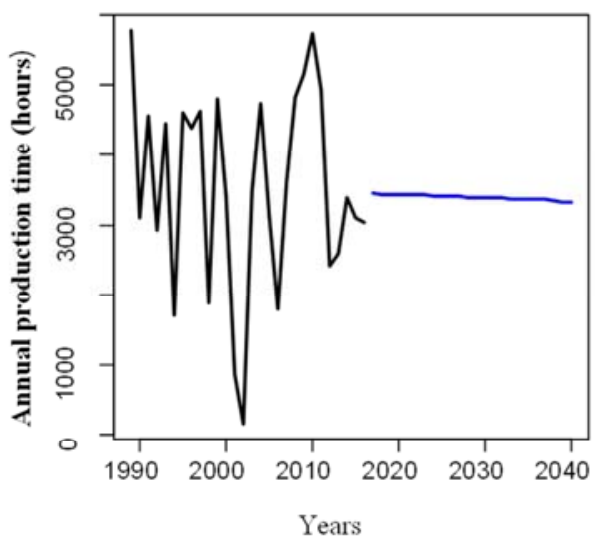

(c)

\subsection{Site of Kétou}

\subsubsection{Simulation of the Annual Production Time}

Figure 9 shows the number of annual production hours at the Kétou site for the respective periods of 1989-2016 and 2017-2040. A careful look at the graph shows that the singleturbine and triple- turbine options presented almost identical trends. In the case of two turbines, there is a break point leading to a discontinuity in the production time between 2020 and 2030

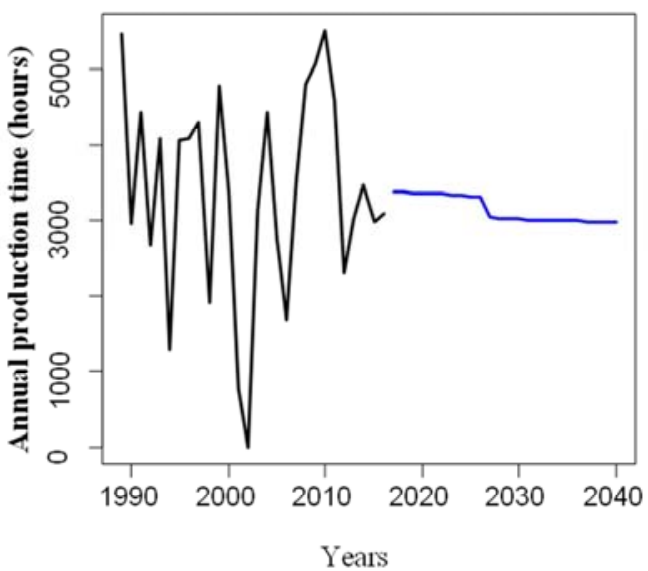

(b)

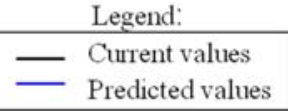

Figure 9. Annual production time for periods of 1989-2016 and 2017-2040 at Kétou site. (a) Case of a Single turbine of $145 \mathrm{~m}^{3} / \mathrm{s}$; (b) Case of Double turbines of $72,5 \mathrm{~m}^{3} / \mathrm{s}$; (c) Case of Triple turbines of $50 \mathrm{~m}^{3} / \mathrm{s}$.

Table 5 summarizes the values of production times over the periods 1989-2016 and 2017-2040. These values indicate that the single-turbine hydropower energy generation option of $145 \mathrm{~m}^{3} / \mathrm{s}$ is the one with the highest rate of decline of $9.21 \%$, unlike the triple turbine option of $50 \mathrm{~m}^{3} / \mathrm{s}$ which appears better with regard to annual hydropower energy production time at Kétou. The triple turbine option not only encounters the lowest drop rate $(4.21 \%)$, but also offers, over the future period (2017-2040), the highest rate of production time in the order of $26.26 \%$ compared to the 145 single turbine option. 
Table 5. Annual production time of hydropower energy at Savè site.

\begin{tabular}{|c|c|c|c|c|}
\hline $\begin{array}{l}\text { Annual mean production time for } \\
\text { the period: }\end{array}$ & Units & $\begin{array}{l}\text { Single Turbine }\left(145 \mathrm{~m}^{3} / \mathrm{s}\right) \\
\text { option }\end{array}$ & $\begin{array}{l}\text { Double Turbine ( } 72.5 \\
\left.\mathrm{~m}^{3} / \mathrm{s}\right) \text { option }\end{array}$ & $\begin{array}{l}\text { Triple Turbine }\left(50 \mathrm{~m}^{3} / \mathrm{s}\right) \\
\text { option }\end{array}$ \\
\hline $1989-2016$ & $\mathrm{H}$ & 2,960 & 3,377 & 3,543 \\
\hline $2017-2040$ & $\mathrm{H}$ & 2,688 & 3,150 & 3,394 \\
\hline Drop rate & $\%$ & 9.21 & 6.72 & 4.21 \\
\hline
\end{tabular}

\subsubsection{Simulation of the Potential Hydropower Energy}

\section{a. Monthly Distribution of the Potential Hydropower Energy}

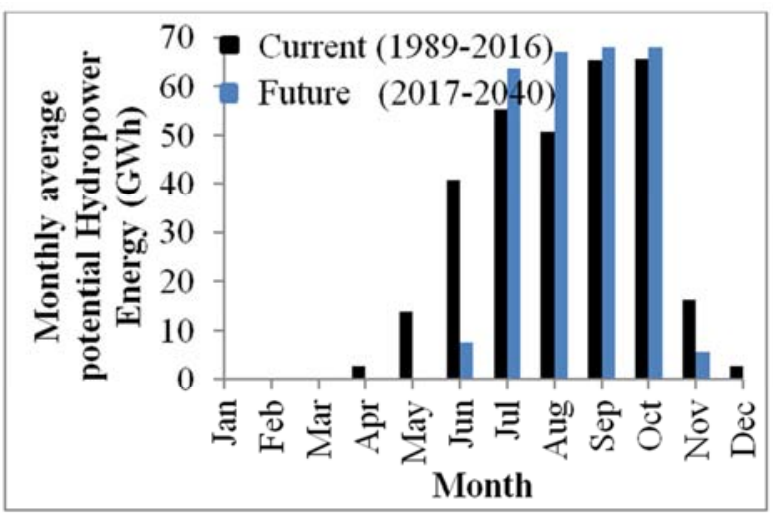

(a)

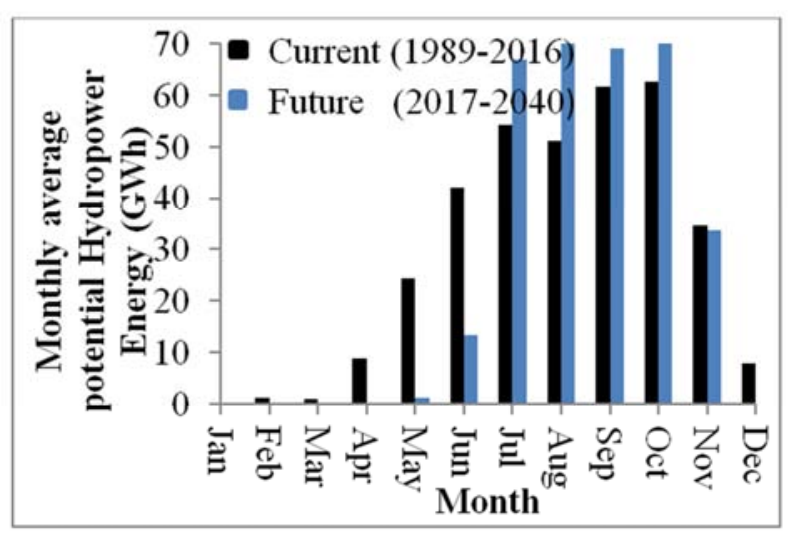

(b)

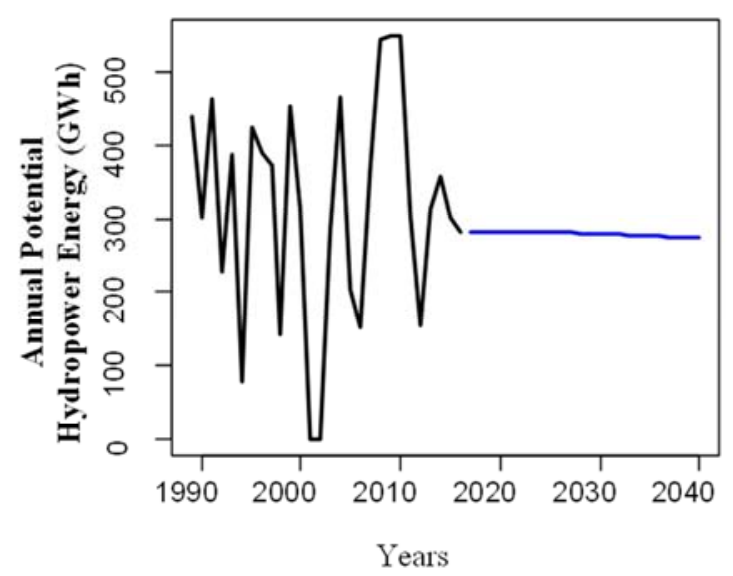

(a)

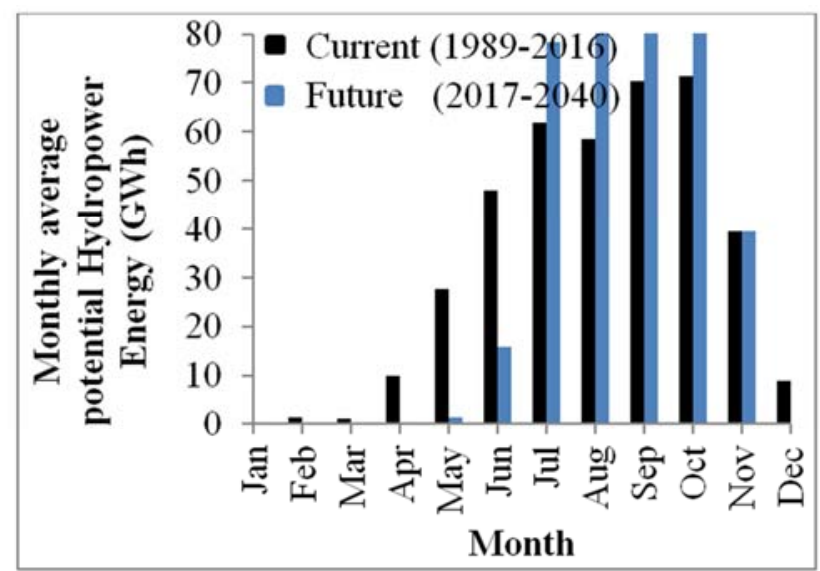

(c)

Figure 10. Monthly mean potential hydropower energy of the Ouémé river basin for periods of 1989-2016 and 2017-2040 at Kétou site. (a) Case of a Single turbine of $145 \mathrm{~m}^{3} / \mathrm{s}$; (b) Case of Double turbines of $72.5 \mathrm{~m}^{3} / \mathrm{s}$; (c) Case of Triple turbines of $50 \mathrm{~m}^{3} / \mathrm{s}$.

Figure 10 shows the monthly production of electrical energy on Ouémé River in Kétou. The production is spread out from June to November in the period 1989 to 2016 . For the forecasted period of 2017-2040 the production covers the period of July to November for the three options assessed. It is also noticed that forecasted productions could quantitatively exceed the current ones from July to October in Kétou. In addition, it is generally observed from these graphs that the distribution of the annual potential hydropower energy of Ouémé basin could be narrowed.

\section{b. Evolution of Potential Hydropower Energy Production Over Time}

Figure 11 shows the annual potential hydropower energy following the three turbine options at the Kétou site.

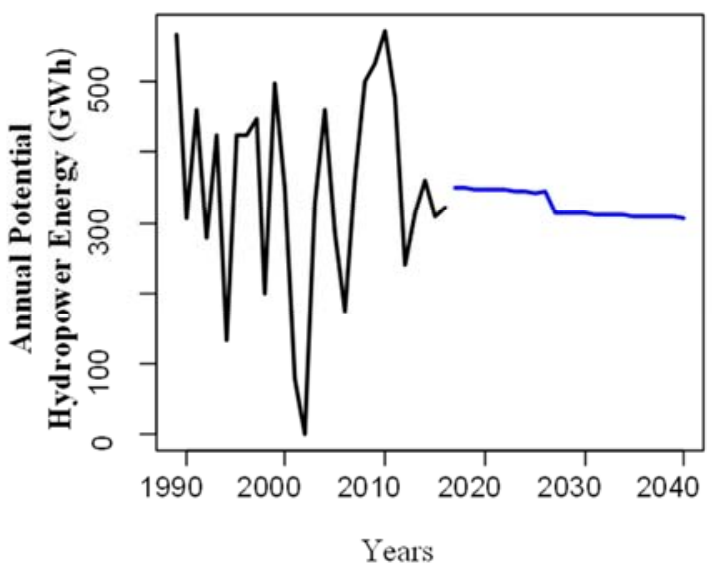

(b) 

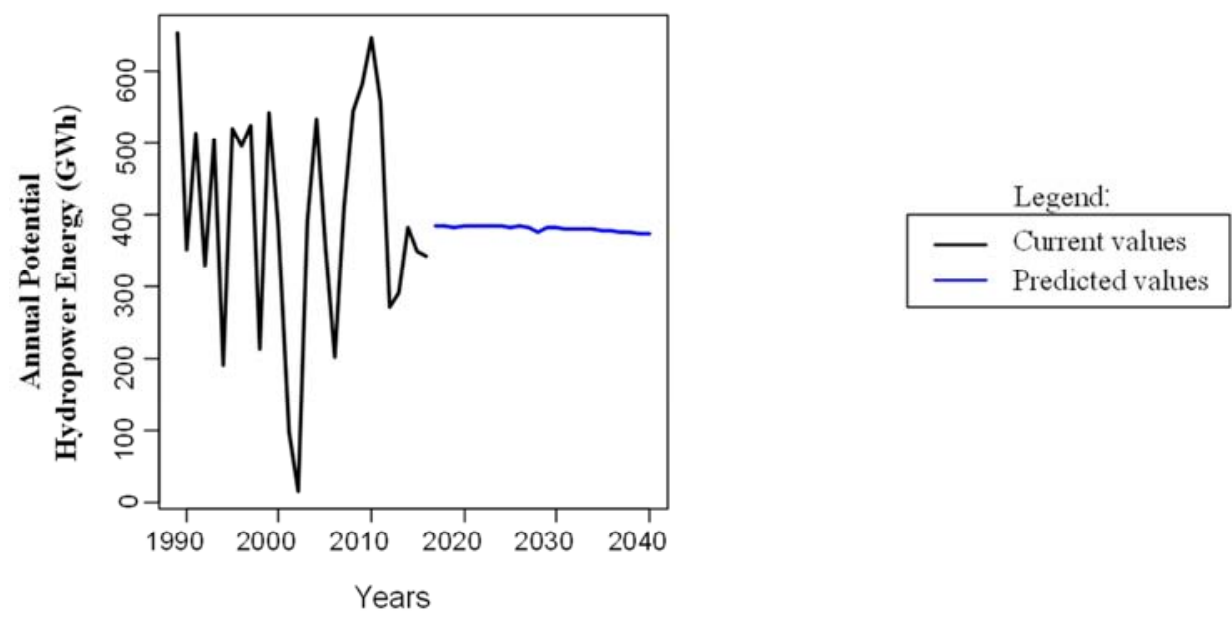

(c)

Figure 11. Annual potential hydropower energy over time for periods of 1989-2016 and 2017-2040 at Kétou site. (a) Case of a Single turbine of $145 \mathrm{~m}^{3} / \mathrm{s}$; (b) Case of Double turbines of $72.5 \mathrm{~m}^{3} / \mathrm{s}$; (c) Case of Triple turbines of $50 \mathrm{~m}^{3} / \mathrm{s}$

Figure 6 shows the gradual reduction of the annual potential hydropower energy over time, regardless of the chosen turbine option. As with the annual production time, forecast productions are showing a decreasing pace. However, it is clear that the one and three-machines options of hydropower energy generation present the same behavior in their forecast periods with significant increases comparatively to two-machines energy generation option. The patterns of the hydropower energy generation graphs are almost similar to those obtained for production times in all the three options. This suggests that the method of determining the nominal flow rate minimizes the impacts of climate change on electrical power based on the hydrological flow (a natural climatic parameter) solely, in contrast to the production time. The production time could be well controlled using water resources management tools. Table 6 presents the statistics on the annual mean potential hydropower energy for the considered period at Kétou site.

Table 6. Annual average potential hydropower energy at Kétou site.

\begin{tabular}{|c|c|c|c|c|}
\hline $\begin{array}{l}\text { Annual mean potential for the } \\
\text { period: }\end{array}$ & Units & $\begin{array}{l}\text { Single Turbine }\left(90 \mathrm{~m}^{3} / \mathrm{s}\right) \\
\text { option }\end{array}$ & $\begin{array}{l}\text { Double Turbine }\left(45 \mathrm{~m}^{3} / \mathrm{s}\right) \\
\text { option }\end{array}$ & $\begin{array}{l}\text { Triple Turbine }\left(30 \mathrm{~m}^{3} / \mathrm{s}\right) \\
\text { option }\end{array}$ \\
\hline $1989-2016$ & GWh & 316.26 & 351.13 & 400.49 \\
\hline $2017-2040$ & GWh & 279,56 & 325,96 & 381,35 \\
\hline
\end{tabular}

From Table 6, it is observed that the single-turbine hydropower energy generation option with $145 \mathrm{~m}^{3} / \mathrm{s}$ water flow-rate has the highest drop rate of $11.60 \%$, unlike the triple-turbines option using $50 \mathrm{~m}^{3} / \mathrm{s}$ which is better in terms of annual hydropower energy production quantity (400 $\mathrm{GWh}$ ) in Kétou. The triple-turbines option not only makes it possible to achieve the lowest drop rate $(4.78 \%)$, but also offers, over the forecasted period (2017-2040), the highest rate of production time in the order of $26.69 \%$ as compared with the single turbine option with $145 \mathrm{~m}^{3} / \mathrm{s}$ water flow-rate.

\section{Conclusion}

The production of hydropower energy is mainly influenced by the flow of watercourses. Changes in the flow of watercourse under the influence of climate or other hazards automatically lead to changes in capacity of the hydropower energy generation. Obtained results of this study showed that the capacity of hydropower energy generation is not the same at the three representative sites of Ouémé River Basin. It is highly dependent on the available hydrological regime, and therefore depends on the effects induced by local climatic factors. Results of achieved simulations prove that Kétou site offers better hydropower energy exploitation prospects than those available respectively in Bétérou and Savè. It is therefore imperative that any attempt of exploring the potential of any of the three studied sites, should consider the particularities of selected site. Moreover, results from analysis of the annual production times and annual mean potential hydropower energy have clearly indicated that the fractional implementation by several turbines usage of reduced capacity is the best option for management of the available water flow-rate, contrary to the single turbine approach of equal capacity to the sum of fractional turbines' capacities.

\section{References}

[1] IHA. Hydropower status, Report, International Hydropower Association: London, United Kingdom, 2015; pp.73.

[2] Primature, Evaluation de la politique de gestion des ressources en eau au Bénin, Rapport, Laboratoire Amen: Cotonou, Benin, 2012, pp.126. 
[3] Minville, M., Krau, S., Brissette, F. and Leconte, R. Behaviour and performance of a water resource system in Québec (Canada) under adapted operating policies in a climate change context, Water Resour. Manag., 24, 2010, pp. 1333-1352.

[4] Haguma, D. Gestion des ressources hydriques adaptée aux changements climatiques pour la production optimale d'hydroélectricité étude de cas: bassin versant de la rivière manicouagan, Thèse de doctorat, Universite de Sherbrooke, Canada, 2013, pp. 267.

[5] GIEC. Bilan des changements climatiques. Contribution des groupes de travail I, II, III au quatrième rapport d'évaluation du climat, Rapport; Groupe d'experts Intergouvernemental sur l'Evolution du Climat: Genève, Suisse, 2007, pp. 103.

[6] Nicholson, S. E. Climatic and environmental change in Africa during the last two centuries, Clim. Res., 17(2), 2001, pp. 123144 .

[7] Le Lay, M. Modélisation hydrologique dans un contexte de variabilité hydro-climatique : une approche comparative pour l'étude du cycle hydrologique à méso-échelle au Bénin, Thèse de doctorat, Institut National Polytechnique de Grenoble, France, 2006, pp. 251.

[8] Desjarlais, C., and Da Silva, L. L'impact économique des changements climatiques sur la production hydroélectrique du Saint-Laurent, Rapport présenté à la Division des impacts et de l'adaptation liés aux changements climatiques, Ressources naturelles Canada et au Gouvernement du Québec, Montréal, Canada, 2016, pp.16.

[9] Boucher, M. A., Changements climatiques et production hydroélectrique canadienne: où en sommes-nous?, Canadian Water Resour. J., 38(3), 2013, pp. 196-209.

[10] Barthel, R., Jagelke, J., Gaiser, T., Printz, A. and Götzinger, J. Aspects of choosing appropriate concepts for modelling groundwater resources in regional Integrated Water Resources Management. Examples from the Neckar (Germany) and Ouémé catchment (Benin), Phys. Chem. Earth, 33(1-2), 2008, pp. 92-114.

[11] Bossa, Y. A. Multi-scale modeling of sediment and nutrient flow dynamics in the Ouémé catchment (Benin), towards an assessment of global change effects on soil degradation and water quality, Thesis $(\mathrm{PhD})$, University of Bonn, Germany, 2012, pp. 110.

[12] Lawin, A. E. Analyse climatologique et statistique du régime pluviométrique de la Haute Vallée de l'Ouémé à partir des données AMMA - CATCH Bénin, Thèse de Doctorat, Institut National Polytechnique de Grenoble, France, 2007, pp. 211.

[13] Diekkrüger, B., Busche, H., Giertz, S. and Steup, G. Hydrology, In: Impacts of Global Change on the Hydrological Cycle in West and Northwest Africa. Speth, P., Christoph, M. and Diekkrüger, B. (Eds.). Springer, Heidelberg, Germany, 2010, pp. 60-64.

[14] Beven, K. J. Rainfall-runoff modeling: the primer, $2^{\text {nd }}$ ed, John Wiley and sons, Chichester, England, 2001, pp. 360.

[15] Arnold, J., Srinivasan, R., Muttiah, R. S. and Williams, J. R. Large area hydrologic modeling and assessment part I: Model development, J. Am. Water Resour. Assoc., 34(1), 1998, pp. 73-89.

[16] Nounangnonhou, T. C., Fifatin, F.-X. N., Lokonon, B. E., Acakpovi, A. and Sanya, E. A. Modelling and Prediction of Ouémé (Bénin) River Flows by 2040 Based on GR2M Approach, Larhyss journal (under review).

[17] Rebillard, V. Détermination et mise en place des régimes réservés pour les cours d'eau, Synthèse technique réalisé au Centre d'Etude du Machinisme Agricole, du Génie Rural, des Eaux et des Forêts (CEMAGREF) Lyon, France, 2006, pp. 26.

[18] Chapallaz, J. M., and Heer, F. Le choix, le dimensionnement et les essais de réception d'une mini-turbine, Berne, Suisse, ISBN 3-905232-57-X, 1995, pp. 75.

[19] Zannou A. Analyse et modélisation du cycle hydrologique continental pour la gestion intégrée des ressources en eau au Bénin: cas du bassin de l'Ouémé à Bétérou, Thèse de doctorat, Université d'Abomey-Calavi, Bénin, 2011, pp. 315.

[20] Chékété, G., Dagba, C., Agbo, J., Nassirou, T. and Houngninou, B. E. Politique et stratégie de développement du secteur de l'énergie électrique au Bénin, Rapport, Cotonou, Bénin, 2008, pp. 117. 